\title{
Risk Management in Public Procurement Process
}

\author{
Ioana Livia Manea, „Al. I. Cuza” University of Iasi, Romania \\ Ioana Anda Popa, „Al. I. Cuza” University of Iasi, Romania
}

\begin{abstract}
Public procurement represents an important part of the current economy reality. Throughout the procurement process, due to the effect of the interaction among the components of the public procurement system, certain actions with significant negative effects on its optimal operation may occur. Risks may turn into certainty either because of a simple error in the development and administration of the procurement process, or because of a deliberate deviation from the existing legal provisions. Therefore, there is an imperative for the implementation of certain risk-avoiding measures, as well as of measures aiming to reduce their negative effects in case of their occurrence.
\end{abstract}

\section{Keywords}

Public procurement, risk management, tender, contracting authority, ethical behaviour, transparency

\section{JEL Codes: H 44, M10}

\section{Public Procurement in EU}

The European Commission Treaty does not include any provisions on public procurement and, for a long time - the Member States have not considered this field as representing a problem for the internal market. Public procurement contracts ${ }^{1}$ were administrated within internal market protection, and the main goals were represented by the internal industry support and workforce employment promotion. However, the use of public funds was characterized by inefficiency.

Although the first public procurement directives came into effect in 70's, they were either not implemented in the national legislation, or not correctly applied. The Document for the Establishment of the Single European Market and the White Paper of the "Internal Market Completion" (1985) were recognized as important improvements in this field. These documents were about public procurement, and to the opening and liberalization of public procurement markets.

In EU, there is a set of directives regarding to the public procurements according to their object:

- Product Supply Contracts - these are contracts by onerous title, focused on a contracting authority's procurement of property, utilization or exploitation rights on mobile goods included in the civil circuit, with or without the purchase obligation. Moreover, these contracts will also include installation and bringing into service;

\footnotetext{
${ }^{1}$ Contracts that include both the category of sector contracts, by onerous title, which are concluded, in written, between one or several contracting authorities, on the one hand, and one or several business operators, on the other, in view of a public procurement and focused on execution of works, supply of products or of services according to the provisions of public procurement legislation
} 
- Service Supply Contracts - these are contracts by onerous title, focused on one of the following types of works that are to be ordered and accepted by a contracting authority: execution (including planning) and execution - by any manner or means, of a work according to the requirements submitted by the existing contracting authority;

- Contracts for Works - these are contracts by onerous title that are not described by the definition provided for the first two categories of contracts, and which are focused on an activity that has been especially ordered by a contracting authority. Most frequently, the procured services belong to the following fields - publicity, management of buildings, cleaning, management consultant, financial services and ITC, telephony, satellite communication, etc;

In 2004, the European Union updates, simplifies and improves the legislation referring to public contract awarding procedures, a legislation that is applicable in the member states.

\section{National awarding processes and EU financing awarding processes}

The national system of public procurement is governed by the same set of rules as the European public procurement system. The contracts financed from the European budget are awarded according to the Romanian legislation in force. The European system is governed by the European directives, which are transposed in the internal law. The differences between the two systems are related to the application scope, since the national system establishes similar awarding rules below the European value thresholds.

Table no. 1. Comparison between the national system and the European public procurement system

\begin{tabular}{|c|c|}
\hline NATIONAL SYSTEM & EUROPEAN SYSTEM \\
\hline 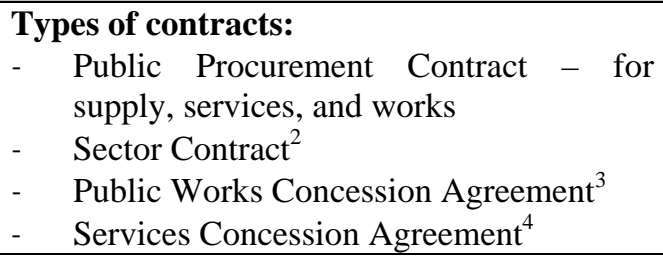 & $\begin{array}{l}\text { Types of contracts: } \\
\text { - } \quad \text { Public Procurement Contract - for } \\
\text { supply, services, and works } \\
\text { - } \quad \text { Sector Contract } \\
\text { - } \quad \text { Public Works Concession Agreement } \\
\text { - } \quad \text { Services Concession Agreement }\end{array}$ \\
\hline $\begin{array}{l}\text { Public law authorities, public enterprises and } \\
\text { business operators developing relevant } \\
\text { activities are generally called "contracting } \\
\text { authorities" }\end{array}$ & $\begin{array}{l}\text { Public law authorities are called } \\
\text { "contracting authorities" } \\
\text { Public enterprises and business operators } \\
\text { developing relevant activities are generally } \\
\text { called "contracting entities" }\end{array}$ \\
\hline $\begin{array}{l}\text { Public procurement awarding procedure } \\
\text { open tender, restricted tender, negotiatio }\end{array}$ & $\begin{array}{l}\text { Public procurement awarding procedures: } \\
\text { open tender, restricted tender, negotiation, }\end{array}$ \\
\hline
\end{tabular}

${ }^{2}$ It refers to that particular public tender contract that is attributed for the development of a relevant activity in sectors of public utility - water, energy, transport, mail. It may be awarded only by a public enterprise developing relevant activities, with any lawful subject, which develop relevant activities based on a special or an exclusive right, or by a public law authority developing a relevant activity

${ }^{3}$ This contract has the same characteristics as the contracts for works, except that - the contractor, as grantee, receives from the contracting authority, as grantor, in counter-performance for the works that are to be developed, the works exploitation right or this right is accompanied by payment.

${ }^{4}$ This contract has the same characteristics as the contracts for works, except that - the contractor, as licensee, is granted by the contracting authority, as licensor, in counter-performance for the works that are to be developed, the service exploitation right or this right is accompanied by payment. 


\begin{tabular}{|c|c|}
\hline competitive dialog, contest of solutions & competitive dialog, contest of solutions \\
\hline $\begin{array}{l}\text { Simplified awarding procedures for public } \\
\text { procurement or direct procurement contracts: } \\
\text { call for tender, direct purchase }\end{array}$ & $\begin{array}{l}\text { There is no simplified awarding procedure } \\
\text { for public procurement contracts. }\end{array}$ \\
\hline $\begin{array}{l}\text { National value thresholds for the application } \\
\text { of open tender and restricted tender } \\
\text { procedures for the award of public } \\
\text { procurement contracts: } \\
\text { - } 75000 \text { EURO for supply and service } \\
\text { agreements } \\
\text { - } 500000 \text { EURO for contracts for works }\end{array}$ & $\begin{array}{l}\text { European value thresholds }{ }^{5} \text { for the } \\
\text { application of open tender, restricted tender } \\
\text { and negotiation procedures for the award of } \\
\text { public contracts: } \\
-137000 \text { EURO for supply and service } \\
\text { contracts awarded by central contracting } \\
\text { authorities } \\
\text { - } 211000 \text { EURO for supply agreements } \\
\text { awarded by contracting authorities in the } \\
\text { field of defense, as well as for service } \\
\text { supply agreements awarded by local } \\
\text { contracting authorities } \\
-5278000 \text { EURO for contracts for works }\end{array}$ \\
\hline $\begin{array}{l}\text { National value thresholds for the application } \\
\text { of open tender and restricted tender } \\
\text { procedures for the award of sector } \\
\text { procurement contracts: } \\
\text { - } 75000 \text { EURO for supply and service } \\
\text { agreements } \\
\text { - } 500000 \text { EURO for work contracts }\end{array}$ & $\begin{array}{l}\text { European value } \text { thresholds }^{6} \text { for the } \\
\text { application of open tender, restricted tender } \\
\text { and negotiation procedures for the award of } \\
\text { contract by an entity developing relevant } \\
\text { activities: } \\
\text { - } 422000 \text { EURO for supply and service } \\
\text { agreements } \\
\text { - } 5278000 \text { EURO for work contracts }\end{array}$ \\
\hline $\begin{array}{l}\text { The advertising service agreement is } \\
\text { governed by special regulation. }\end{array}$ & $\begin{array}{l}\text { There are no special regulations for the } \\
\text { advertising service agreement, which is } \\
\text { construed as an ordinary service agreement. }\end{array}$ \\
\hline $\begin{array}{l}\text { The service concession contract is awarded } \\
\text { following the same rules as the public works } \\
\text { concession contract. }\end{array}$ & $\begin{array}{l}\text { There are no particular regulations for the } \\
\text { service concession contract. }\end{array}$ \\
\hline $\begin{array}{l}\text { The right to appeal is acknowledged for } \\
\text { business operators, regardless of the public } \\
\text { procurement/sector contract value. } \\
\text { No differences are set between the classical } \\
\text { system and the utility one. }\end{array}$ & $\begin{array}{l}\text { The right to appeal is acknowledged in the } \\
\text { case of business operators for public } \\
\text { procurement contract values that are bigger } \\
\text { than or equal to the European thresholds. } \\
\text { Only the appeal elaborated against contracts } \\
\text { concluded by entities developing relevant } \\
\text { activities may be settled by conciliation. }\end{array}$ \\
\hline
\end{tabular}

(Source: www.mie.ro)

\section{Public procurement principles in practice}

Public procurement principles play an essential part in legislation enforcement, if one also considers the fact that this legislation may not refer to all practical situations. These principles are the following ones:

The contracting authority must guarantee the non-discriminating and equal treatment for all business operators, and it must encourage competition among them. The contracting

\footnotetext{
${ }^{5}$ European Commission Regulation No. 2083/2005, published in the Official Journal of the European Union 333/20.12.2005

${ }^{6}$ Ibid 5
} 
authority shall not bias any of the involved business operators, and it will not provide any of the involved parties with unjustified advantages throughout the procedures. All business operators will have access to the same information package throughout the public procurement process.

Mutual acknowledgement is one of the essential principles of EU and of the Community legislation. The contracting authority must secure mutual acknowledgement and the same conditions for EU business operators and for the products and services supplied or the works performed by these business operators on the EU market.

Transparency: public fund use publicity and control must be provided in order to reduce corruption. It is important for the contracting authority to permanently inform business operators on all the activities and all the data referring to the procedure.

Proportionality - it refers to securing the correlation between: the needs of the contracting authority; the object of the public procurement contract; the requirements that must be met.

Efficient use of funds - this requires the authority to consider the economic advantages of the submitted offers, in order to obtain the optimal price-quality relation.

Accountability - the contracting authority has the obligation to choose the most advantageous solution from the professional and economic perspectives that is provided on the market by an appropriate enforcement and observance of the public procurement legislation, as well as the obligation to adapt these solutions to its procurement needs by applying a particular awarding procedure. In order to achieve this, it is necessary for correctly prepared awarding procedure to consider the professional content and the schedule of the awarding procedure. The contract awarding criterion should not be the best price offer, but the offer that is the most advantageous from an economic perspective, taking into account, beside the price, other qualitative, as well as quantifiable criteria.

\section{Risks in public procurement process}

The public procurement system represents a significant part of the Romanian economic reality, having the same characteristics, both strong points and weaknesses. Here are the components of the public procurement system: the regulatory authority; contracting authorities; business operators; system supervisors.

Various relations occur among these elements in order to achieve the general purpose, as elements interact and condition one another, enhancing or annihilating one another. Therefore, throughout the interaction among the components of the system, throughout the procurement process, such actions may occur with negative effects on the entire system.

Risks - from the ethical perspective during the procurement process, refer to those uncertain, but probable events, whose occurrence may generate damage or negative impacts on certain community specific values.

One must underline the fact that risks may become certain either because of a simple error in the development and administration of the procurement process, or because of a deliberate deviation from the existing legal provisions.

In the public procurement process, the occurrence probability of a negative element is tightly connected to the value of the budget granted for that particular contract.

At the European level, a set of risks have been identified, which are manifested throughout the development of any public procurement process, and which are construed as having general validity and applicability, considering the stage and relation in the public procurement process, according to the table below:

Table no. 2. Risks of public procurement process

\begin{tabular}{|l|l|l|}
\hline \multicolumn{1}{|c|}{ STAGE } & OPERATION & \multicolumn{1}{c|}{ RISKS } \\
\hline $\begin{array}{l}\text { Elaboration of } \\
\text { the annual }\end{array}$ & $\begin{array}{l}\text { Needs } \\
\text { idendification }\end{array}$ & $\begin{array}{l}\text { ' High-level official authorities' involvement in the } \\
\text { procurement decision }\end{array}$ \\
\hline
\end{tabular}




\begin{tabular}{|c|c|c|}
\hline \multirow[t]{7}{*}{$\begin{array}{l}\text { public } \\
\text { procurement } \\
\text { programme }\end{array}$} & & $\begin{array}{l}\text { - The procurement is not economically justified or it } \\
\text { is environmentally harmful } \\
\text { - Lack of communication among compartments in } \\
\text { view of an accurate identification of needs } \\
\text { - Identification of needs after budget approval }\end{array}$ \\
\hline & $\begin{array}{l}\text { Contract value } \\
\text { estimation }\end{array}$ & $\begin{array}{l}\text { - Superficial evaluation of the contract value without } \\
\text { considering all the costs that may be incurred } \\
\text { - Over-assessment in order to encourage a certain } \\
\text { contracting party } \\
\text { - Use of a calculation model leading to a value that } \\
\text { may not correspond to the application of a } \\
\text { competitive procedure }\end{array}$ \\
\hline & $\begin{array}{l}\text { CPV } \\
\text { Correspondence } \\
7\end{array}$ & $\begin{array}{l}\text { - Superficial identification of the appropriate } \\
\text { procurement code }\end{array}$ \\
\hline & $\begin{array}{l}\text { Hierarchies and } \\
\text { priorities }\end{array}$ & $\begin{array}{l}\text { - Influence of external actors, such as politicians, } \\
\text { consultants, etc. }\end{array}$ \\
\hline & $\begin{array}{l}\text { Choice of } \\
\text { procedure }\end{array}$ & $\begin{array}{l}\text { - Abusive use of uncompetitive procedures invoking } \\
\text { the existence of legal exceptions } \\
\text { - Division of contracts with similar objects into small } \\
\text { value contracts, invoking different goals } \\
\text { - Abusive use of extreme emergency situations }\end{array}$ \\
\hline & $\begin{array}{l}\text { Identification of } \\
\text { funds }\end{array}$ & $\begin{array}{l}\text { - Unrealistic grant of the budget, which is based } \\
\text { merely on cost records, not on covering the existing } \\
\text { needs }\end{array}$ \\
\hline & $\begin{array}{l}\text { Calendar } \\
\text { elaboration }\end{array}$ & $\begin{array}{l}\text { - Faulty planning of the procurement process } \\
\text { - Insufficient time allotment for the appropriate } \\
\text { development of each stage }\end{array}$ \\
\hline \multirow[t]{4}{*}{$\begin{array}{l}\text { Elaboration of } \\
\text { the awarding } \\
\text { documentation }\end{array}$} & $\begin{array}{l}\text { Identification of } \\
\text { technical } \\
\text { specification }\end{array}$ & $\begin{array}{l}\text { - Specification adjustment in order to correspond to a } \\
\text { single business operator } \\
\text { - Specification adjustment to the unjustified request } \\
\text { of a decisional factor at the level of the contracting } \\
\text { authority } \\
\text { - Identification of unclear specifications or of } \\
\text { specifications that do not observe the envisaged } \\
\text { performance level } \\
\text { - Frequent and unjustified meetings with the preferred } \\
\text { bidder for consultations on technical requirements }\end{array}$ \\
\hline & $\begin{array}{l}\text { Establishing of } \\
\text { contract clauses }\end{array}$ & $\begin{array}{l}\text { - Identification of general clauses that are not } \\
\text { specifically related to the contracting authority's } \\
\text { need and to the object of the contract } \\
\text { - Imposing excessive penalties }\end{array}$ \\
\hline & $\begin{array}{l}\text { Establishing } \\
\text { minimum } \\
\text { qualification } \\
\text { requests }\end{array}$ & $\begin{array}{l}\text { - Requests “customized" for certain business } \\
\text { operators, accompanied by superficial justifying } \\
\text { documents, with no real support }\end{array}$ \\
\hline & $\begin{array}{l}\text { Establishing the } \\
\text { selection }\end{array}$ & $\begin{array}{l}\text { - They are not clearly and objectively defined } \\
\text { - The evaluation factors leave room for speculations }\end{array}$ \\
\hline
\end{tabular}

\footnotetext{
${ }^{7}$ Public procurement common vocabulary
} 


\begin{tabular}{|c|c|c|}
\hline & $\begin{array}{l}\text { criteria and/or } \\
\text { the awarding } \\
\text { criterion }\end{array}$ & \\
\hline & $\begin{array}{l}\text { Filling-in the } \\
\text { procurement } \\
\text { chart, } \\
\text { establishing } \\
\text { forms and } \\
\text { models }\end{array}$ & $\begin{array}{l}\text { - They are filled-in superficially, with no } \\
\text { consideration for procurement specificity, and } \\
\text { leaving room for speculations }\end{array}$ \\
\hline & $\begin{array}{l}\text { Establishing the } \\
\text { bid submission } \\
\text { deadline }\end{array}$ & $\begin{array}{l}\text { - Establishing an insufficient period of time for bid } \\
\text { preparation }\end{array}$ \\
\hline & $\begin{array}{l}\text { Awarding } \\
\text { documentation } \\
\text { completion }\end{array}$ & $\begin{array}{l}\text { - Inappropriate verification, which generates } \\
\text { contradictory information } \\
\text { - Absence of internal audit procedures }\end{array}$ \\
\hline \multirow[t]{3}{*}{$\begin{array}{l}\text { Call for } \\
\text { competition }\end{array}$} & $\begin{array}{l}\text { Participation } \\
\text { advertising }\end{array}$ & - Resistance to the use of other press informing means \\
\hline & $\begin{array}{l}\text { Availability of } \\
\text { the awarding } \\
\text { documentation }\end{array}$ & $\begin{array}{l}\text { - Resistance to the use of several methods to provide } \\
\text { free documentation availability }\end{array}$ \\
\hline & $\begin{array}{l}\text { Response to } \\
\text { clarification } \\
\text { requests }\end{array}$ & $\begin{array}{l}\text { - Providing evasive answers or answers that change } \\
\text { the specifications included in the documentation } \\
\text { without giving business operators enough time to } \\
\text { adapt to the submitted clarifications }\end{array}$ \\
\hline \multirow[t]{7}{*}{$\begin{array}{l}\text { Awarding } \\
\text { procedure } \\
\text { development }\end{array}$} & $\begin{array}{l}\text { Assignment of } \\
\text { the evaluation } \\
\text { commission }\end{array}$ & $\begin{array}{l}\text { - Assignment of persons that aim to fulfill certain } \\
\text { interests or who have no knowledge of the existing } \\
\text { legal provisions }\end{array}$ \\
\hline & $\begin{array}{l}\text { Candidature } \\
\text { acceptance and } \\
\text { candidate } \\
\text { selection }\end{array}$ & $\begin{array}{l}\text { - Business operators are considered qualified by } \\
\text { accepting authorizations or certifications that do not } \\
\text { correspond to real facts }\end{array}$ \\
\hline & $\begin{array}{l}\text { Development of } \\
\text { discussions } \\
\text { rounds }\end{array}$ & - Revealing confidential information to the candidates \\
\hline & Bid acceptance & $\begin{array}{l}\text { - Establishing the bid acceptance deadline long before } \\
\text { the opening meeting }\end{array}$ \\
\hline & Opening of bids & $\begin{array}{l}\text { - Bid opening procedure flaws } \\
\text { - Deviations from the correct bid opening procedure }\end{array}$ \\
\hline & $\begin{array}{l}\text { Examination, } \\
\text { offer evaluation } \\
\text { and } \\
\text { establishment of } \\
\text { the winning bid }\end{array}$ & $\begin{array}{l}\text { - Familiarity with bidders in time, manifesting } \\
\text { personal interests } \\
\text { - Animosity to certain bidders } \\
\text { - Errors or omissions throughout the evaluation in } \\
\text { favour of certain bidders }\end{array}$ \\
\hline & $\begin{array}{l}\text { Cancellation of } \\
\text { procedure (is } \\
\text { necessary) }\end{array}$ & $\begin{array}{l}\text { - Unjustified (easy) identification of cancellation } \\
\text { reasons }\end{array}$ \\
\hline \multirow{3}{*}{$\begin{array}{l}\text { Public } \\
\text { procurement } \\
\text { contract } \\
\text { awarding or } \\
\text { framework } \\
\text { agreement }\end{array}$} & $\begin{array}{l}\text { Results } \\
\text { notification }\end{array}$ & $\begin{array}{l}\text { - The result notification is lapidary without } \\
\text { mentioning the advantages of the winning bid }\end{array}$ \\
\hline & $\begin{array}{l}\text { Waiting period } \\
\text { and settlement } \\
\text { of appeals }\end{array}$ & $\begin{array}{l}\text { - Agreements are concluded with claimants in order } \\
\text { to withdraw their appeals }\end{array}$ \\
\hline & Signing the & - When the contract is signed, modifications occur \\
\hline
\end{tabular}




\begin{tabular}{|c|c|c|}
\hline \multirow[t]{2}{*}{ conclusion } & $\begin{array}{l}\text { contract / } \\
\text { framework } \\
\text { agreement } \\
\text { conclusion }\end{array}$ & $\begin{array}{l}\text { compared to the awarding documentation and to the } \\
\text { bid, motivating that they have been omitted or that } \\
\text { the need has not been well quantified }\end{array}$ \\
\hline & $\begin{array}{l}\text { Transmission } \\
\text { for the awarding } \\
\text { advertisement }\end{array}$ & - Non-transmission of the awarding advertisement \\
\hline $\begin{array}{l}\text { Conclusion of } \\
\text { the public } \\
\text { procurement } \\
\text { file }\end{array}$ & $\begin{array}{l}\text { Finalization of } \\
\text { the public } \\
\text { procurement } \\
\text { file }\end{array}$ & $\begin{array}{l}\text { - The existence of sporadic records and subsequent to } \\
\text { the occurrence of the events } \\
\text { - Random archiving of files }\end{array}$ \\
\hline $\begin{array}{l}\text { Development of } \\
\text { contract } \\
\text { framework } \\
\text { agreement }\end{array}$ & $\begin{array}{l}\text { Fulfillment of } \\
\text { undertaken } \\
\text { obligations and } \\
\text { partial } \\
\text { acceptance }\end{array}$ & $\begin{array}{l}\text { - Absence of a real monitoring system regarding the } \\
\text { cost-quality and time perspectives for a contract } \\
\text { - Substantial modifications in the contract conditions } \\
\text { in view of longer periods and higher prices for the } \\
\text { contracting party } \\
\text { - Frequent and unjustified meetings with the } \\
\text { contracting party } \\
\text { - Accepted modifications of the contract } \\
\text { specifications below the level of the standards } \\
\text { imposed by the documentation } \\
\text { - Delayed payment of bills, postponements of } \\
\text { payments in view of price revision, in order to } \\
\text { increase contract values } \\
\text { - Temporary advance payments, with no reasons }\end{array}$ \\
\hline $\begin{array}{l}\text { Contract } \\
\text { completion }\end{array}$ & $\begin{array}{l}\text { Final } \\
\text { acceptance }\end{array}$ & $\begin{array}{l}\text { - No supervision of contractual obligations, from the } \\
\text { cost, quality and time perspectives } \\
\text { - Artificial invoicing for something that has not been } \\
\text { yet finalized }\end{array}$ \\
\hline $\begin{array}{l}\text { Process } \\
\text { analysis }\end{array}$ & $\begin{array}{l}\text { Conclusions } \\
\text { and } \\
\text { improvement } \\
\text { measures }\end{array}$ & $\begin{array}{l}\text { - No process analysis to establish whether the } \\
\text { expected value has been achieved }\end{array}$ \\
\hline
\end{tabular}

In order to avoid the risks identified above, but also in order to observe the principles that govern the awarding procedures of public procurement contracts, the following activities must be taken into account:

- Establishing a frameworks that is relied on trust, correctness and impartiality;

- Limiting those elements of a subjective nature that influence decisions in the awarding process of public procurement contracts;

- Eliminating the preferential treatment granted to local business operators;

- Securing the "visibility" of rules, opportunities, internal procedures, and of results;

- Eliminating restrictive, abusive requirements;

- Obtaining the best value for public funds, which are always considered as insufficient in relation to the existing needs;

- Monitoring the costs generated by the development of the public procurement process, which includes the costs related to the administration of the process at the contracting authority level, as well as the bid preparation related costs;

- Limiting error occurrence throughout the public procurement process;

- Limiting fraud and corruption phenomena;

- Developing a healthy public procurement market; 


\section{Conclusions}

The commitment and the attitude of decisional factors within the contracting authorities in relation to public procurement ethical issues are major conditions for the application of certain measures for the implementation of the above-mentioned activities.

It is well known that an ethical procurement behaviour which is accepted by all the parties involved in the procurement process may limit or even avoid consequences of the following manifestations:

- Unfair competition, as well as any action or deed that is contrary to fair usages in product purchasing, works performance and service supply activities;

- Active corruption, which refers to someone deliberately promising, offering or giving, directly or indirectly, an undeserved benefit to an office holder, for personal or someone else's advantage, in order to perform or hinder the performance of an activity implied by their functions;

- Passive corruption, which refers to an office holder deliberately requiring or receiving, directly or indirectly, an undeserved benefit to an office holder, for personal or someone else's advantage, or accepting an offer or the promise of such benefits, in order to perform or hinder the performance of an activity implied by their functions;

- Conflict of interests, which refers to the situation when an employee of the contracting authority has a personal interest of a patrimonial nature that may influence the objective fulfillment of the tasks implied by their public position.

The ethical procurement behaviour is represented by the use of a set of principles and rules, which all lead to the unaltered maintenance of social values.

\section{Bibliography}

1. Ghidul pentru atribuirea contractelor de achizitii publice (Public Procurement Contract Awarding Guidelines), published in Official Journal no. 894 bis/2.11.2006

2. Atribuirea contractelor de achizitie publica si a contractelor de concesiune-Manual de traning (Awarding Public Procurement Contracts and Concession Contracts - Training Manual), Ministry of Regional Development and Tourism

3. www.mie.ro

4. Cod de conduita etica privind achizitiile publice (Ethical Code for Public Procurement), Ministry of Regional Development and Tourism

5. Propuneri privind completarea si actualizarea ghidului pentru atribuirea contractelor de achizitie publica (Suggestions for the Completion and Update of the Public Procurement Awarding Guidelines), Ministry of Regional Development and Tourism

6. Fighting corruption and promoting integrity in public procurement, OECD

7. www.sourceoecd.org

8. www.sar.org.ro

9. Guidelines for awarding public procurement contracts, Official Gazette, No 894, November 2006

10. Performanta de mediu in achizitiile publice - aspecte legate de coerenta politicii (Environmental Performance in Public Procurement - policy coherence related aspects), OECD, September $19^{\text {th }} 2003$

11. Recomandarea Consiliului privind imbunatatirea performantei de mediu in achizitiile publice (Council's Recommendation for Improved Environmental Performance in Public Procurement), OEC, January $23^{\text {rd }} 2002$

12. Ghid pentru achizitiile publice durabile si eficiente din punctul de vedere al costului (Guidelines for Cost Efficient and Sustainable Public Procurements), ICLEI, second edition, 2007

13. Integrity in Public Procurement Good practice from A To Z - OECD Organisation for Economic Co-Operation and Development 